Model Pemberdayaan Masyarakat untuk Mencegah Kekerasan dalam Rumah Tangga (Sigit Sanyata, Siti Rohmah Nurhayati, Kartika Nur Fathiyah)

\title{
MODEL PEMBERDAYAAN MASYARAKAT UNTUK MENCEGAH KEKERASAN DALAM RUMAH TANGGA
}

\author{
Oleh: \\ Sigit Sanyata Siti Rohmah Nurhayati, Kartika Nur Fathiyah \\ Staf Pengajar FIP UNY
}

\begin{abstract}
The aim of this research is to produce a model of social empowerement to restrain domestic violence. As the first target is to identify understanding, necessity and design society empowerment model as mean to restrain domestic violence.

This research, as the first year step, used research and development approach. The participans engaged in this research are 150 people spread in Bantul, Yogyakarta, and Kulonprogo. Sixty people are socialites as FGD subjects and 90 people were determined to fill in questionaire. FGD guide has been arranged to expose society's potentials whilst the questionaire was to identify society understanding abouut domestic violence. Qualitative data were analyst descriptively and the quantitative were analyst descriptive-quantitatively.

The results of the analysis are 1) society understanding of domestic violence still at cognitive level. 2) society has a comprehension that domestic violence could be prevented through society participations. 3) people need a model of domestic violence prevention. 4) tho odel of society empowerement is focused on optimalization of human, natural and social resources. The effort of empowerment has been done in three steps; increasing people awareness, capaciting and empowering.
\end{abstract}

Key words: society empowerement, domestic violence

\section{PENDAHULUAN}

Kekerasan terhadap perempuan senantiasa muncul dalam berbagai karakteristik perkembangan dan perilaku masyarakat, baik dalam keadaan dan kondisi apapun. memiliki peluang yang tidak sama dibandingkan dengan pihak laki-laki. Bukti-bukti mencatat bahwa angka kekerasan dalam rumah tangga (domestic violencel KDRT) dan kekerasan dalam pacaran (dating rape) dari tahun ke 
tahun menunjukkan angka yang cukup tinggi dengan mayoritas korbannya adalah kaum perempuan. Rifka Annisa Women's Crisis Center mencatat bahwa dari tahun 1994-2005 terdapat 3.115 kasus kekerasan terhadap perempuan, $63 \%$ diantaranya kasus kekerasan terhadap istri sedangkan $37 \%$ kasus lainnya dikategori sebagai kekerasan dalam pacaran, pelecehan seksual, perkosaan dan kekerasan dalam keluarga (Rifka Annisa, 2005). Tingginya kasus kekerasan terhadap istri merupakan cerminan bahwa sebagian masyarakat masih memandang rendah terhadap peran dan fungsi istri dalam rumah tangga. Kondisi ini sebenarnya berseberangan dengan munculnya UU No. 23 tahun 2004 tentang Penghapusan Kekerasan Dalam Rumah Tangga, sebagai payung hukum atas kekerasan yang terjadi dalam sektor domestic

Bias-bias gender akhirnya membawa persoalan gender menjadi lebih rumit dan tidak mudah untuk diurai, hal ini tidak lebih karena masyarakat menempatkan makna gender seperti halnya jenis kelamin yang melekat secara permanen dan tidak dapat dipertukarkan. Perbedaan antara perempuan dan laki-laki secara esensial membawa implikasi ke dalam berbagai sektor kehidupan. Laporan dari Rosen-Gardon (2004) menyebutkan bahwa di USA dari seluruh perkawinan setengah hingga dua pertiga pasangan suami istri berakhir dengan perceraian, data mencatat bahwa $77 \%$ perempuan dan $84 \%$ laki-laki dari pasangan yang bercerai menikah kembali dengan pasangan barunya dan dari pernikahan yang kedua ini sebesar $60 \%$ bercerai kembali. Data tersebut menunjukkan bahwa besarnya angka menikah kembali di kalangan laki-laki merupakan stereotypes laki-laki yang selama ini dianggap lebih kuat dan cenderung memiliki kemerdekaan untuk bertindak.

Deborah Sinclair (1999) memberikan batasan kekerasan terhadap perempuan dalam rumah tangga yaitu kekerasan terhadap perempuan dalam hubungan intim mencakup usaha-usaha dari pasangan untuk mengintimidasi, baik dengan ancaman atau melalui penggunaan kekuatan phisik untuk menyerang tubuh perempuan 
atau barang-barang miliknya. Tujuan dari serangan tersebut adalah mengendalikan tingkah laku perempuan atau memunculkan rasa takut. Undang-undang RI Nomor 23 Tahun 2004 tentang Penghapusan Kekerasan dalam Rumah Tangga yang dimaksud kekerasan dalam rumah tangga adalah;

"setiap perbuatan terhadap seseorang terutama perempuan yang berakibat timbulnya kesengsaraan atau penderitaan secara phisik, seksual, psikologis dan/atau penelantaraan rumah tangga termasuk ancaman untuk melakukan perbuatan, pemaksaan atau perampasan kemerdekaan secara melawan hukum dalam lingkup rumah tangga (pasal 1)."

Sinclair (1999) mendeskripsikan tiga bentuk kekerasan yang dialami oleh istri, yaitu kekerasan fisik, kekerasan seksual dan kekerasan psikologis. Komnas Perempuan (2002: 74-77) membagi kekerasan dalam rumah tangga terutama terhadap istri adalah kekerasan fisik, kekerasan psikologis, kekerasan berdimensi ekonomi dan kekerasan seksual.

Selama ini, masyarakat tampak belum dilibatkan secara optimal untuk mengatasi kekerasan dalam rumah tangga. Kekerasan dalam rumahtangga lebih banyak ditangani oleh lembagalembaga yang concern untuk menanganinya, misalnya LSM, Untuk itu dibutuhkan suatu upaya sistematis untuk memberdayakan masyarakat dalam mengatasi KDRT. Pemberdayaan masyarakat menurut Ife dan Tesoriero (2006) merupakan suatu upaya meningkatkan keberdayaan masyarakat untuk mengatasi kondisi yang merugikan (disanvantaged), dalam hal ini adalah untuk mengatasi semakin maraknya kekerasan dalam rumah tangga. Pemberdayaan masyarakat ini merupakan suatu proses yang bersifat multi aspek, baik ditinjau dari sumber daya alamnya (natural recources), sumber daya sosial (human recources), serta sumber daya sosial (social recources) melalui pemanfaatan sumberdaya-sumberdaya ini seoptimal mungkin (Soetomo, 2009). Dalam berbagai kesempatan, sumber daya sosial sering disebut 
sebagai modal sosial. Modal sosial secara sederhana dapat didefinisikan sebagai serangkaian nilai-nilai dan norma-norma informal yang dimiliki bersama di antara anggota kelompok masyarakat yang memungkinkan terjalinnya kerjasama di antara mereka (Fukuyama, dalam (Soetomo, 2009).

Langkah awal yang perlu dilakukan di masyarakat adalah penyadaran secara penuh akan kesamaan derajat, hak, dan kewajiban antara pria dan wanita serta menepis bias gender berupa anggapan bahwa perempuan dicitrakan sebagai makhluk yang lemah, tergantung, lembut, emosional, keibuan, pemelihara, indah. Sedangkan laki-laki distereotipkan kuat, gagah, kasar, rasional, jantan dan perkasa, sehingga memiliki kekuasaan penuh atas perempuan. Munculnya bias-bias berakibat berkembangnya konstruksi sosial dalam masyarakat yang menempatkan gender secara tidak setara. Ketidaksetaraan ini dipengaruhi oleh stereotype yang terbangun dalam masyarakat dengan menempatkan posisi dan peran perempuan kurang menguntungkan. Langkah awal adalah mewujudkan kesadaran di kalangan masyarakat akan arti penting tanggung jawab masing-masing anggota masyarakat untuk membangun serta mewujudkan kesetaraan gender dan menghindari munculnya bias gender pada berbagai aspek kehidupan atas tanggung jawab sendiri

Setelah kesadaran diperoleh, langkah selanjutnya adalah pengkapasitasan. Pengkapasitasan masyarakat merupakan salah satu proses dimana masyarakat setelah melalui proses ini pada akhirnya memiliki kemampuan untuk mewujudkan sendiri kesetaraan gender di lingkungan masyarakatnya. Setelah proses penyadaran dan pengkapasitasan masyarakat berjalan dengan optimal, pada akhirnya dapat dicapai proses pemberdayaan masyarakat untuk mencegah KDRT di masyarakat. Melalui capaian proses pemberdayaan ini dapat diperoleh keberdayaan masyarakat yang secara teknis bersandar pada kemampuan, prakarsa, dan partisipasi masyarakat sendiri untuk mengatasi kondisi yang merugikan (disanvantaged) karena adanya KDRT. 
Terkait pemberdayaan masyarakat untuk mencegah KDRT, fokus perubahan lebih ditekankan pada perubahan secara partisipatif. Menurut Adi (2004), ciri khas model intervensi di level makro atau komunitas adalah partisipasi. Model ini dilandasi asumsi bahwa masyarakat tahu apa yang sebenarnya mereka butuhkan dan apa yang baik untuk mereka. Pemeran utama dalam perubahan adalah masyarakat itu sendiri. Agen perubahan lebih bersifat menggali dan mengembangkan potensi masyarakat. Masyarakat diberi kesempatan untuk membuat analisis dan mengambil keputusan yang berguna bagi bagi mereka sendiri, serta diberi kesempatan penuh dalam penentuan cara-cara untuk mencapai tujuan yang mereka inginkan.

\section{Cara Penelitian}

Penelitian dilakukan dengan pendekatan Research and Development yakni suatu rangkaian kegiatan penelitian yang ditindaklanjuti dengan pengembangan model pemberdayaan masyarakat dalam berpartisipasi dalam mencegah kekerasan dalam rumah tangga. Model pengembangan dalam penelitian ini mengacu pada rancangan model dari Borg and Gall (1983). Untuk mengumpulkan data dalam penelitian ini digunakan angket dan diskusi terfokus. Adapun data yang akan dieksplorasi dalam need assessment yaitu pemahaman masyarakat terhadap kekerasan dalam rumah tangga; dan sumber daya yang dimiliki dalam upaya mencegah kekerasan dalam rumah tangga. Pemahaman kekerasan dalam rumah tangga diukur dengan skala sedangkan data tentang potensi sumber daya masyarakat daya dieksplorasi dengan diskusi terfokus (FGD). FGD bertujuan untuk mengelaborasi pola-pola pemberdayaan dalam masyarakat. Partisipan berasal dari dua wilayah yaitu Kabupaten Kulonprogo dan Kabupaten Bantul. Subyek terdiri dari 150 orang, 90 orang sebagai partisipan dalam pemahaman KDRT sedangkan 60 orang berpartisipasi dalam FGD.

Model dirancang berdasar kajian konseptual tentang konseling dalam perspektif sistem di mana proses konseling 
bersifat preventif-developmental dan melibatkan masyarakat sekitar untuk peduli pada problem yang muncul di lingkungannya. Kajian konseptual dipadukan dengan temuan-temuan pada studi pendahuluan untuk dirumuskan sebagai model hipotetik pemberdayaan masyarakat untuk mencegah kekerasan dalam rumah tangga. Model hipotetik akan diuji coba pada tahun kedua. Teknik analisis data dilakukan dengan teknik deskriptif. Analisis untuk menggambarkan keterkaitan antar variabel pemahaman kekerasan dalam rumah tangga dilakukan dengan uji statistik ( $t$-test).

Kategorisasi skor subyek dengan pendekatan kategorisasi ordinal. Menurut Azwar (1999), tujuan kategorisasi ini adalah untuk menempatkan individu ke dalam kelompok-kelompok yang terpisah secara berjenjang menurut suatu kontinum berdasar atribut yang diukur. Dalam penelitian ini, penulis menempatkan subyek dalam lima kategori sesuai dengan atribut yang diukur dalam masing-masing variabel.

Tabel 1. Norma Kategorisasi Skor Pemahaman terhadap KDRT

\begin{tabular}{|l|l|}
\hline Kategori & Interval Skor \\
\hline Sangat tinggi & $\mu+1,5 \sigma<X$ \\
\hline Tinggi & $\mu+0,5 \sigma<X \leq \mu+1,5 \sigma$ \\
\hline Sedang & $\mu-0,5 \sigma<X \leq \mu+0,5 \sigma$ \\
\hline Rendah & $\mu-1,5 \sigma<X \leq \mu+0,5 \sigma$ \\
\hline Sangat rendah & $X \leq \mu-1,5 \sigma$ \\
\hline
\end{tabular}

Keterangan:

$\mu=$ rerata skor hipotetik

$\sigma=$ deviasi standar skor hipotetik

$\mathrm{X}=$ skor subyek

\section{PEMBAHASAN}

Pemahaman Kekerasan Dalam Rumah Tangga 
Salah satu hal yang perlu diketahui dalam analisis kebutuhan ini adalah tingkat pemahaman masyarakat terhadap kekerasan dalam rumah tangga. Berdasarkan analisis data sebelumnya diketahui bahwa rata-rata empiris skor pemahaman terhadap KDRT adalah 34,79 dengan SD 4,418. Sementara itu ratarata hipotetiknya adalah 25 dengan SD 8,16.

Tabel 2. Kategorisasi Skor Pemahaman terhadap KDRT

\begin{tabular}{|l|c|c|c|}
\hline \multicolumn{1}{|c|}{ Kategori } & Interval & Jumlah (orang) & Persentase (\%) \\
\hline Sangat tinggi & $37-49$ & 30 & $33,33 \%$ \\
\hline Tinggi & $29-36$ & 55 & $61,11 \%$ \\
\hline Sedang & $21-28$ & 5 & $5,55 \%$ \\
\hline Rendah & $13-20$ & 0 & \\
\hline Sangat rendah & $0-12$ & 0 & \\
\hline Jumlah & 90 & $100,00 \%$ \\
\hline
\end{tabular}

Berdasarkan Tabel 2 dapat diketahui bahwa mayoritas subyek berada pada kategori tinggi dan sangat tinggi, yaitu sebanyak 55 orang atau $61,11 \%$ dari subyek memiliki pemahaman terhadap KDRT yang tinggi dan 30 atau 33,33\% subyek memiliki pemahaman yang sangat tinggi terhadap KDRT, dan hanya 5 atau $5,55 \%$ yang memiliki tingkat pemahaman yang sedang terhadap KDRT. Berdasarkan hasil analisis data juga dapat diketahui bahwa tidak ada perbedaan pemahaman terhadap KDRT antara subyek laki-laki dan perempuan, antar subyek dengan tingkat pendidikan yang berbeda, antar kelompok usia yang berbeda, antar subyek dengan jenis pekerjaan yang berbeda, serta antar subyek dengan status pernikahan yang berbeda. Ringkasan hasil analisis tersebut dapat dilihat pada Tabel 3. 
Tabel 3. Ringkasan hasil analisis perbedaan pemahaman KDRT ditinjau dari jenis kelamin, usia, tingkat pendidikan, jenis pekerjaan, dan status pernikahan

\begin{tabular}{|l|c|c|c|}
\hline \multicolumn{1}{|c|}{ Variabel } & Mean & F & Sig \\
\hline Jenis Kelamin & 34,79 & 0,010 & 0,991 \\
\hline Usia & 34,79 & 1,591 & 0,171 \\
\hline Tingkat Pendidikan & 34,79 & 2,094 & 0,089 \\
\hline Jenis Pekerjaan & 34,79 & 2,338 & 0,049 \\
\hline Status Pernikahan & 34,79 & 1,390 & 0,255 \\
\hline
\end{tabular}

Pada Tabel 3 terlihat bahwa tidak ada perbedaan pemahaman KDRT antara subyek laki-laki dan perempuan yang ditunjukkan dengan nilai $\mathrm{F}$ 0,010 ( $\mathrm{p}>0,05$ ), dan antar subyek pada kelompok usia yang berbeda, yaitu kelompok usia di bawah 20 tahun, kelompok usia 21-30 tahun, kelompok usia 31-40 tahun, kelompok usia 41-50 tahun, dan kelompok usia di atas 50 tahun yang ditunjukkan dengan nilai $\mathrm{F}$ sebesar 1,591 ( $\mathrm{p}>0,05)$. Demikian juga tidak ada perbedaan pemahaman KDRT yang signifikan antar subyek dengan tingkat pendidikan yang berbeda, yaitu tidak lulus SD, SD, SMP, SMA, dan perguruan tinggi yang ditunjukkan dengan nilai $F$ sebesar 2,094 ( $p>0,05)$, serta tidak ada perbedaan pemahaman KDRT yang signifikan antara subyek dengan status pernikahan sudah menikah dan belum menikah yang ditunjukkan dengan nilai $F$ sebesar 1,390 ( $p>0,05)$. Sementara itu Tabel 3 juga menunjukkan bahwa ada perbedaan pemahaman KDRT antar subyek dengan jenis pekerjaan yang berbeda yaitu Pegawai Negeri Sipil, Karyawan swasta, buruh, dan ibu rumah tangga, serta jenis pekerjaan selain yang sudah disebut. Namun demikian perbedaan tersebut tidak cukup signifikan yang ditunjukkan dengan nilai $\mathrm{F}$ sebesar 1,390 (p hampir mendekati 0,05 yaitu 0,049).

Hal tersebut sejalan dengan hasil Focus Group Discussion (FGD) yang dilakukan pada beberapa kelompok subyek. 
Berdasarkan hasil FGD dapat diketahui bahwa pada dasarnya masyarakat sudah memahami kekerasan dalam rumah tangga. Misalnya pendapat dari salah satu ibu peserta FGD yang menyatakan bahwa "KDRT itu tidak hanya kekerasan secara fisik akan tetapi juga kekerasan yang bersifat psikis, seperti membentak atau berperilaku yang membuat istri sakit hati”. Hal yang kurang lebih sama dinyatakan oleh salah seorang remaja peserta FGD, bahwa "KDRT adalah kekerasan fisik maupun non fisik yang dilakukan oleh suami kepada istrinya".

Namun demikian, sebagian masyarakat masih menilai bahwa kekerasan dalam rumah tangga hanyalah sebatas kekerasan fisik saja. Sebagai contoh adalah pendapat dari seorang remaja peserta FGD bahwa " KDRT adalah tindakan yang melibatkan fisik dan biasanya yang menjadi korban perempuan yang disebabkan hal yang sepele". Namun demikian secara keseluruhan subyek peserta FGD memiliki pemahaman yang cukup memadai tentang KDRT.

\section{Kasus Kekerasan Dalam Rumah Tangga}

Adanya kasus-kasus kekerasan dalam rumah tangga yang diketahui oleh masyarakat juga ditemukan dalam survey melalui angket. Berdasarkan hasil analisis data diketahui bahwa 48 orang atau 53,33\% subyek mengaku mengetahui adanya kasus kekerasan dalam rumah tangga yang terjadi di kampung atau desanya. Sementara itu 41 orang atau 45,56\% dari subyek menyatakan tidak mengetahui adanya kasus kekerasan dalam rumah tangga. Para subyek yang mengetahui adanya kasus kekerasan dalam rumah tangga mengetahui melalui beberapa cara. Dua puluh empat orang atau $26,67 \%$ subyek menyatakan melihat atau mendengar secara langsung, 18 orang atau $20 \%$ subyek mengaku diberitahu secara langsung oleh korban, dan 17 orang atau 18,89\% mendengar dari orang lain. 


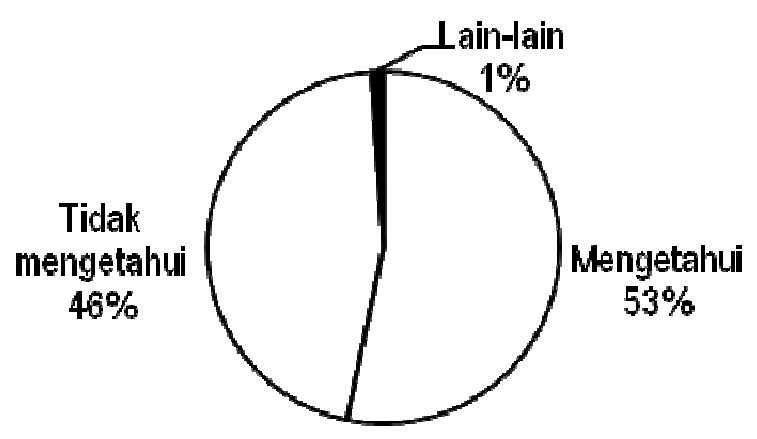

Gambar 1. Masyarakat yang mengetahui dan tidak mengetahui kasus kekerasan dalam rumah tangga

\section{Respon Subyek terhadap Kekerasan Dalam Rumah Tangga}

Terdapat bermacam-macam respon subyek terhadap kekerasan dalam rumah tangga yang diketahuinya. Sebanyak 14 orang atau $15,56 \%$ dari subyek menyatakan pura-pura tidak tahu terhadap kasus tersebut, sebanyak 6 orang atau $6,67 \%$ dari subyek membicarakannya dengan orang lain dan 37 orang atau $41,01 \%$ dari subyek menyatakan membantu korban dengan berbagai cara, seperti menyediakan waktu untuk mendengarkan curahan hati korban, memberikan nasehat, memberikan bantuan materi, mengantarkan korban melapor pada polisi, dan memberikan informasi. 


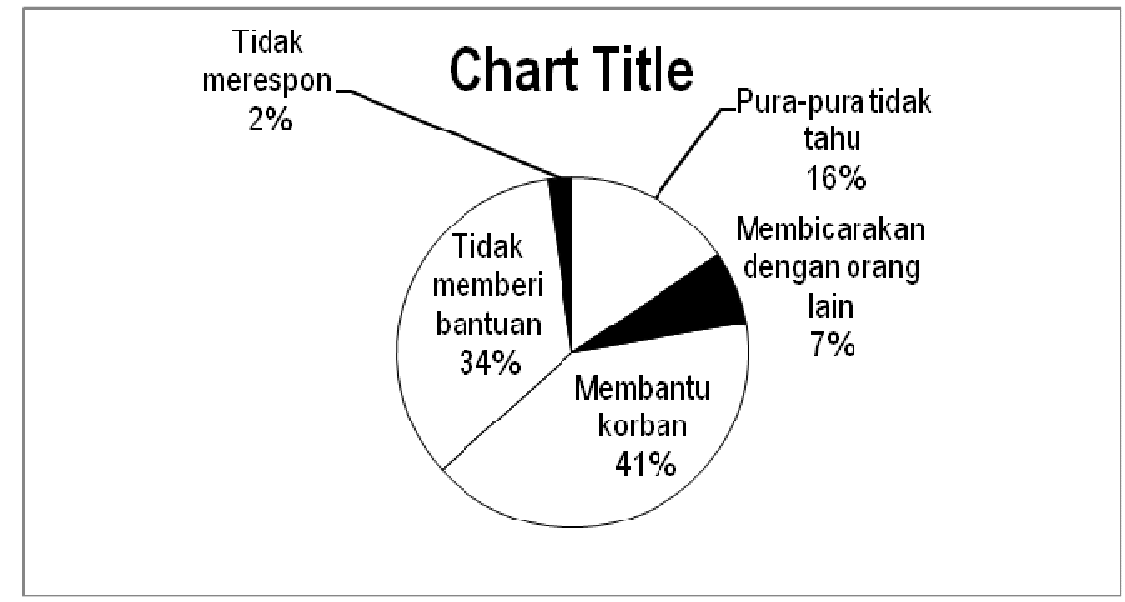

Gambar 2. Respon subyek terhadap kasus kekerasan dalam rumah tangga

Adapun alasan subyek yang tidak memberikan bantuan pada korban sebagian besar (31 orang) adalah karena tidak ingin mencampuri urusan rumah tangga orang lain, takut pada pasangan korban, tidak tahu apa yang harus dilakukan, dan tidak mampu memberikan bantuan.

\section{Persepsi Subyek terhadap Pencegahan KDRT}

Mayoritas subyek yang mengikuti FGD menyatakan bahwa kekerasan dalam rumah tangga dapat dicegah. Hal ini juga tampak pada survey yang dilakukan melalui angket. Sebanyak 60 orang atau $66,67 \%$ dari subyek menyatakan bahwa kekerasan dalam rumah tangga dapat dicegah, sementara 28 orang atau $31,11 \%$ menyatakan bahwa kekerasan dalam rumah tangga tidak dapat dicegah. Berkaitan dengan pihak yang bertanggung jawab untuk mencegah kekerasan, 4 orang atau $6,67 \%$ dari subyek yang menyatakan dapat dicegah berpendapat bahwa kepala dusun bertanggung jawab untuk mencegah KDRT, 15 orang atau $25 \%$ menyatakan ketua RT bertanggung jawab mencegah KDRT, 12 
orang atau $20 \%$ menyatakan tokoh masyarakat bertanggung jawab mencegah KDRT, 8 orang atau $13,33 \%$ menyatakan tokoh agama turut bertanggung jawab mencegah KDRT, 17 orang atau $28,22 \%$ subyek menyatakan semua warga masyarakat turut bertanggung jawab mencegah KDRT, 37 orang atau $61,67 \%$ manyatakan keluarga yang paling bertanggungjawab untuk mencegah KDRT, serta 17 orang atau 28,22 menyatakan keluarga bersama masyarakat bertanggung jawab terhadap pencegahan KDRT.

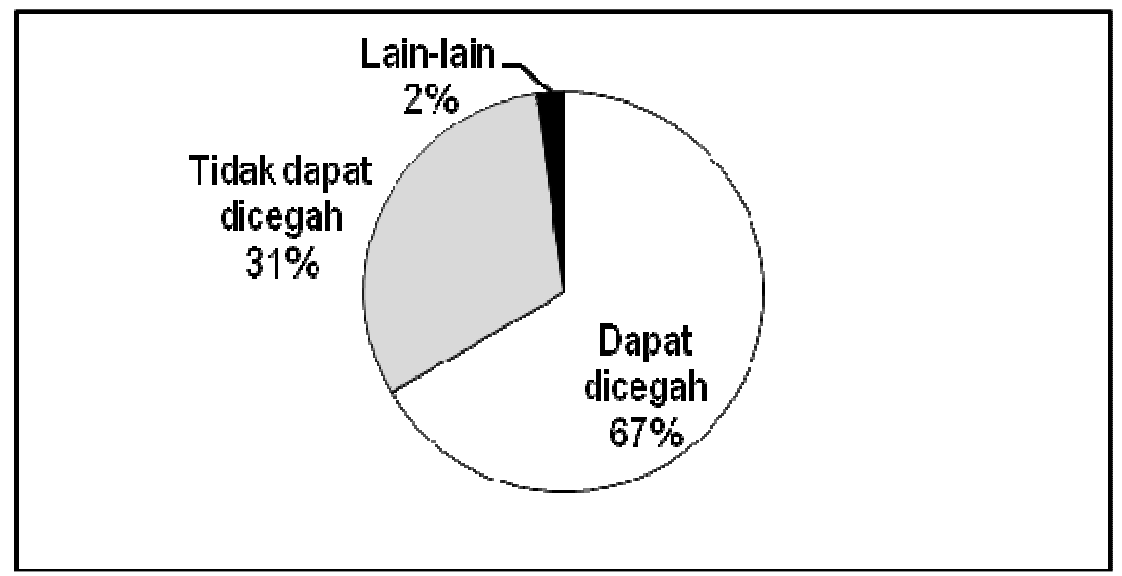

Gambar 3. Persepsi subyek terhadap pencegahan kekerasan dalam rumah tangga

\section{Upaya Pencegahan Kekerasan Dalam Rumah Tangga}

Berdasarkan analisis pada hasil focus group discussion dan analisis instrumen ditemukan ada beberapa pandangan terkait dengan upaya pencegahan kekerasan dalam rumah tangga adalah berupa 1) Sosialisasi atau penyuluhan tentang gender dan UU PKDRT. 2) Pelatihan kader penyuluh gender dan KDRT. 3) Pemberian sanksi bagi pelaku KDRT. 4) Pembentukan lembaga/biro konsultasi keluarga di tingkat desa. 5) Pelatihan kapasitas ekonomi (pelatihan keterampilan) bagi perempuan. 6) Hambatan dalam Upaya Pencegahan Kekerasan Dalam Rumah Tangga. Berdasarkan 
hasil FGD masih ada beberapa upaya yang dapat dilakukan untuk mencegah kekerasan dalam rumah tangga, yaitu 1) Peningkatan pemahaman agama dalam masyarakat, khususnya terkait dengan hak dan kewajiban suami isteri, 2) Meningkatkan rasa saling gotong-royong dan saling membantu, 3) Meningkatkan silahturahmi antar anggota masyarakat, 4) Melaporkan pelaku KDRT pada polisi untuk memberikan efek jera, 5) Peningkatan kapasitas ekonomi masyarakat, baik berupa penyediakan lapangan pekerjaan baru, mendirikan koperasi, pelatihan keterampilan untuk menambah penghasilan masyarakat; serta perlu dibangun sarana dan prasarana yang menunjang untuk kegiatan tersebut. Sementara itu hambatan yang muncul dalam upaya pencegahan KDRT, yaitu 1) Kurangnya keterbukaan dari masyarakat karena sebagian masyarakat memandang masalah KDRT sebagai aib keluarga. 2) Kesulitan dalam melibatkan pihak pelaku KDRT karena kecenderungan pelaku KDRT tidak mau bergaul dengan lingkungan sosial sekitar. 3) Rendahnya kepercayaan diri masyarakat untuk menjadi kader penyuluh. 4) Adanya doktrin dari orang tua jika istri harus menurut/mengalah pada suami. 5) Belum ada orang yang ahli tentang KDRT di desa

Berdasarkan analisis kebutuhan tampak bahwa memiliki pemahaman yang memadai tentang kekerasan dalam rumah tangga. Hal ini merupakan suatu modal positif dalam rangka pencegahan kekerasan dalam rumah tangga. Keragaman latar belakang subyek menunjukkan bahwa tidak ada perbedaan pemahaman terhadap kekerasan dalam rumah tangga berdasar jenis kelamin, usia, tingkat pendidikan, jenis pekerjaan dan status pernikahan. Tingginya pemahaman subyek terhadap kekerasan dalam rumah tangga menunjukkan bahwa masyarakat mampu menyerap informasi dengan cukup baik. Selain itu pemahaman masyarakat tentang kekerasan dalam rumah tangga serta tidak adanya perbedaan pemahaman diantara para subyek tersebut dimungkinkan karena informasi tentang kekerasan dalam rumah tangga sudah meluas, baik melalui media cetak maupun media elektronik. Salah satu hal 
yang kemudian disadari adalah bahwa pemahaman hanya merupakan salah satu kemampuan manusia dalam tataran kognitif. Nampaknya ini merupakan salah satu kelemahan dalam penelitian ini, yaitu kurang mengeksplorasi tataran afektif subyek dalam analisis kebutuhan, mulai dengan penerimaan konsep keadilan gender yang melandasi upaya pencegahan KDRT sampai pada pembentukan pola hidup yang adil gender.

Pada bagian lain ditemukan bahwa lebih dari 50\% subyek mengetahui adanya kasus kekerasan dalam rumah tangga di kampungnya. Hal ini mengindikasikan dua hal. Pertama, angka kasus kekerasan dalam rumah tangga yang cukup tinggi. Kedua, adanya kepekaan dari subyek terhadap kasus kekerasan dalam rumah tangga yang terjadi di sekitarnya. Kepekaan subyek terhadap kasus KDRT merupakan modal awal yang bagus untuk melakukan upaya-upaya pencegahan kekerasan dalam rumah tangga. Meskipun demikian masih ada sebagian yang lain tidak mengetahui adanya kekerasan dalam rumah tangga di sekitarnya. Ketidaktahuan subyek terhadap kasus KDRT dapat memiliki dua makna. Pertama memang tidak ada kasus KDRT di sekitar subyek dan yang kedua adalah subyek kurang peka terhadap lingkungan sehingga tidak mengetahui adanya kasus KDRT.

Berdasarkan data yang telah disebutkan sebelumnya, terdapat beberapa macam respon subyek terhadap kekerasan rumah tangga yang diketahuinya. Yang menarik adalah $41,01 \%$ subyek memberikan bantuan pada korban. Hal ini menunjukkan bahwa subyek memiliki kepedulian terhadap korban. Sementara itu subyek yang tidak memberikan respon membantu menyatakan tidak ingin mencampuri urusan rumah tangga orang lain. Hal ini sesuai pendapat umum di masyarakat bahwa kekerasan dalam rumah tangga adalah masalah domestik sehingga tidak sepantasnya diungkap keluar dan juga tidak sepantasnya orang lain ikut campur. Kenyataan ini merupakan salah satu faktor yang menghambat upaya penghapusan kekerasan dalam rumah tangga. 
Berkaitan dengan pencegahan kekerasan dalam rumah tangga, sebagian besar subyek menyatakan bahwa kekerasan rumah tangga harus dicegah dan dapat dicegah. Menurut subyek, pencegahan dapat dilakukan oleh para tokoh masyarakat, baik tokoh formal maupun informal beserta seluruh warga masyarakat. Tokoh-tokoh seperti kepala dusun, ketua RT, dan pemuka agama diharapkan mampu berperan dalam upaya pencegahan KDRT. Pendapat bahwa kekerasan dalam rumah tangga harus dicegah sangat penting, karena diasumsikan subyek memiliki sikap positif terhadap pencegahan KDRT sehingga mendukung upaya pencegahan kekerasan dalam rumah tangga. Persepsi bahwa KDRT dapat dicegah juga sangat penting karena berkaitan dengan optimisme tentang kemungkinan KDRT dapat dicegah. Optimisme ini akan melahirkan semangat untuk melakukan pencegahan KDRT.

Adapun bentuk-bentuk upaya pencegahan berdasarkan pendapat para subyek sangat bervariasi, yaitu sosialisasi atau penyuluhan gender dan UU PKDRT, pelatihan kader penyuluh gender dan KDRT, pemberian sanksi bagi pelaku KDRT, pelatihan keterampilan bagi perempuan, serta pendirian lembaga konsultasi keluarga di tingkat desa. Bervariasinya pendapat tentang bentuk pecegahan KDRT menunjukkan bervariasinya kebutuhan serta kompleksitas masalah kekerasan dalam rumah tangga. Demikian juga dengan forum serta media yang dapat digunakan untuk melakukan upaya pencegahan KDRT, bervariasi sesuai dengan potensi yang dimiliki oleh masyarakat. Hal ini dimungkinkan karena subyek berasal dari wilayah yang berbeda, latar belakang pendidikan dan pekerjaan yang berbeda, serta kategori usia yang berbeda. Oleh karena itu potensi-potensi yang ada dalam masyarakat ini yang mestinya dimanfaatkan secara maksimal dalam rangka pemberdayaan masyarakat untuk mencegah kekerasan dalam rumah tangga. Selain potensi, hambatan dalam upaya pencegahan KDRT juga mesti diperhatikan.

Pada sebagian kalangan laki-laki masih menganggap bahwa isu kesetaraan adalah ancaman bagi mereka sehingga mereka 
berasumsi bahwa wilayah perempuan bagaimanapun juga berada di wilayah domestik.

Isu feminisme jika tidak dijelaskan secara proporsional sesuai dengan karakter budaya Indonesia akan menjadi ancaman yang serius karena gerakan feminisme radikal turut berkontribusi terhadap pola pikir sebagian masyarakat.

Tidak semua tokoh masyarakat memiliki komitmen untuk mengelimisasi adanya kekerasan dalam rumah tangga karena dipengaruhi oleh keyakinan bahwa hal-hal yang terjadi di dalam keluarga merupakan aib sehingga tidak selayaknya Data penelitian ini secara keseluruhan menampakkan peta pemahaman dan potensi masyarakat dalam mencegah kekerasan dalam rumah tangga. Beberapa kekuatan yang tampak adalah modal sosial masyarakat, pemahaman tentang kekerasan dalam rumah tangga, keinginan untuk mengurangi problem sosial.

Langkah awal yang perlu dilakukan di masyarakat adalah penyadaran secara penuh akan kesamaan derajat, hak, dan kewajiban antara pria dan wanita serta menepis bias gender berupa anggapan bahwa perempuan dicitrakan sebagai makhluk yang lemah, tergantung, lembut, emosional, keibuan, pemelihara, indah, sedangkan laki-laki distereotipkan kuat, gagah, kasar, rasional, jantan dan perkasa, sehingga memiliki kekuasaan penuh atas perempuan. Munculnya bias-bias berakibat berkembangnya konstruksi sosial dalam masyarakat yang menempatkan gender secara tidak setara. Ketidaksetaraan ini dipengaruhi oleh stereotype yang terbangun dalam masyarakat dengan menempatkan posisi dan peran perempuan kurang menguntungkan.

Tahap penyadaran. Pada tahap pendampingan dilakukan dengan pelatihan kader serta sosialisasi pada masyarakat tentang kekerasan dalam rumah tangga. Sosialisasi pada masyarakat dengan memfokuskan pada pemahaman terhadap kekerasan dalam rumah tangga serta aturan-aturan yang menjadi landasan hukumnya. Pelatihan kader akan dirumuskan pada panduan pemberdayaan masyarakat untuk mencegah KDRT dan modul 
pelatihan bagi kader. Langkah ini dibangun dengan mengadakan kerjasama antara pemerintah setempat dengan lembaga pendamping, untuk berkolaborasi dalam melakukan tahap pendampingan. Pemilihan kader didasarkan pada kualifikasi dan pemahaman mereka tentang kesetaraaan gender serta komitmen untuk menjadi personil yang mampu membangun kesadaran masyarakat.

Pada tahap pemberdayaan lebih banyak difokuskan pada partisipasi aktif kader untuk melakukan sosialisasi dan pemberian informasi pada unit-unit sosial yang aktif di dalam masyarakat sehingga seorang kader berasal dari tokoh masyarakat yang memiliki posisi di unit sosial. Seorang ketua RT/RW memiliki kemampuan dalam memberikan informasi tentang upaya-upaya pencegahan kekerasan dalam rumah tangga. Pada tahap pemberdayaan sangat dimungkinkan adanya kerja sama antara masyarakat, kader dan ahli dalam bidang gender sehingga terbentuk pola tripartit yang akan menjadi simbiose mutualisme. 


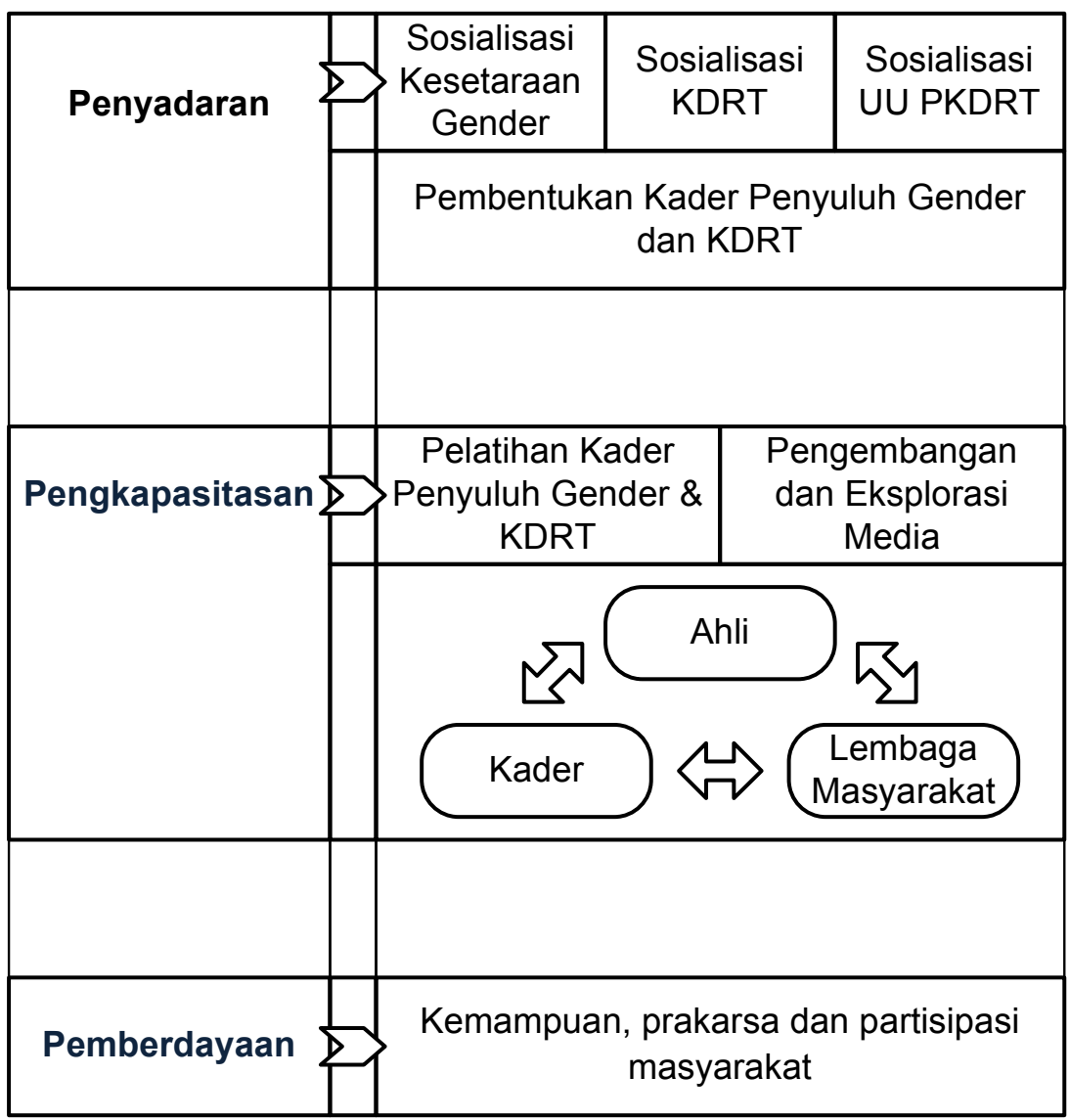

Gambar 4. Model Pemberdayaan Masyarakat untuk Mencegah KDRT

\section{SIMPULAN}

Hasil penelitian pada tahap awal yang dilakukan untuk melakukan analisis kebutuhan dapat disimpulkan bahwa;

Pemahaman masyarakat tentang kekerasan dalam rumah tangga (sektor domestik) masih dalam tataran kognitif belum 
menyentuh pada tahap kesadaran untuk terlibat langsung dalam mencegah terjadinya kekerasan dalam rumah tangga.

Masyarakat cukup memahami bahwa kekerasan dalam rumah tangga dapat dicegah dan memerlukan partisipasi anggota masyarakat dalam pencegahan KDRT.

Ada kebutuhan dari masyarakat untuk memiliki model pencegahan kekerasan dalam rumah tangga dengan melibatkan partisipasi aktif masyarakat.

Model pemberdayaan masyarakat difokuskan pada optimalisasi sumber daya yang ada di masyarakat baik sumber daya alam, sumber daya sosial dan sumber daya manusia. Upaya pemberdayaan dilakukan dalam tiga tahap yaitu tahap penyadaran, pengkapasitasan dan pemberdayaan. Tahap penyadaran adalah upaya membangun kesadaran masyarakat atas kekerasan dalam rumah tangga melalui proses sosialisasi atas KDRT baik pada tataran kognitif maupun aspek legalitas. Tahap pengkapasitasan adalah pelatihan kader dalam rangka menyiapkan potensi yang ada dalam masyarakat dengan kerjasama antara ahli-kader-lembaga masyarakat, sedangkan tahap akhir adalah pemberdayaan yang merupakan kemampuan, prakarsa, dan partisipasi masyarakat secara langsung untuk berkontribusi apda pencegahan kekerasan dalam rumah tangga.

Pemahaman masyarakat tentang kekerasan dalam rumah tangga perlu ditingkatkan menjadi kesadaran atas fenomena sosial tersebut sehingga perlu komitmen pemerintah daerah untuk melakukan pelatihan bagi masyarakat agar masyarakat tidak hanya paham KDRT tetapi memiliki kesadaran untuk berpartisipasi dalam mengatasi fenomena KDRT di daerahnya.

Pemerintah Desa membentuk tim untuk dijadikan kader gender sebagai bentuk tanggung jawab sosial terhadap masyarakat.

Penelitian ini menghasilkan model hipotetik model pemberdayaan masyarakat untuk mencegah kekerasan dalam rumah tangga, dan masih memerlukan eksperimen untuk mengukur 
efektivitas model agar dapat diketahui bahwa salah satu upaya pencegahan KDRT dengan memberdayakan masyarakat.

\section{DAFTAR PUSTAKA}

Adi, R.I. 2004. Ilmu Kesejahteraan Sosial dan Pekerjaan Sosial (Pengantar pada Pengertian dan Beberapa Pokok Bahasan. Jakarta: FISIP UI Press

Borg, W.R. \& Gall, M.D. 1983. Educational Research, An Introduction. Fourth Edition. New York: Longman

Carthy, JM and Holliday, EL. 2004. "Helpseeking and Counseling Within a Traditional Male Gender Role: An Examination from a Multicultural Perspective." Journal of Counseling and Development. (82). 25-30.

Fakih, M. 2008. Analisis Gender dan Transformasi Sosial. Yogyakarta: Pustaka Pelajar

Handayani, T dan Sugiarti. 2002. Konsep dan Teknik Penelitian Gender. Malang. UMM Press.

Ife, J dan Tesoriero, F. 2008. Community Development: Alternatif Pengembangan Masyarakat di Era Globalisasi. Yogyakarta: Pustaka Pelajar

Komnas Perempuan, 2002. Peta Kekerasan: Pengalaman Perempuan Indonesia. Ameepro. Jakarta.

Lips, H.M. 1993. Sex and Gender: An Introduction. London: Mayfield Publishing Company

Nasaruddin Umar. 2001. Argumen Kesetaraan Jender: Perspektif A-Qur'an. Penerbit: Paramadina. Jakarta.

Nilsson, dkk. 2005. Social Justice Advocacy among Graduate in Counseling: An Initial Exploration Journal of College Student 
http://www.findarticles.com/p/articles/mi_qa3752/is_20050 5/ai_n13640714\#continue Rabu, 12 Oktober 2005.

Rosen-Gordon, J., Myers, JE., and Hattie, JA., 2004. "The Relationship Between Marital Characteristic, Marital Interaction Processes and Marital Satisfaction." Journal of Counseling and Development. (82), 58-68.

Sinclair, Deborah. 1999. Memberdayakan Perempuan Korban Kekerasan Dalam Rumah Tangga/Hubungan Intim. (Terjemahan: Betariani \& Kristi Poerwandari). Program kajian Wanita PPs. Universitas Indonesia.

Siti Rohmah Nurhayati, dkk. 2007. Dukungan Sosial dan Strategi Coping pada Perempuan Korban Kekekerasan Dalam Rumah Tangga. Lembaga Penelitian UNY. Tidak Diterbitkan.

Siti Rohmah Nurhayati, dkk. 2008. Pengembangan Buku Panduan Keluarga Adil Gender untuk Mencegah Kekerasan Dalam Rumah Tangga. Lembaga Penelitian UNY. Tidak Diterbitkan.

Soetomo. 2009. Pembangunan Masyarakat: Merangkai Sebuah Kerangka. Yogyakarta: Pustaka Pelajar

Usman, S. 1998. Pembangunan dan Pemberdayaan Masyarakat. Yogyakarta: Pustaka Pelajar. 